\title{
ANALISIS KENDARAAN BERMOTOR RODA DUA BERDASARKAN (BOK) DESA TUMPOK LADANG KECAMATAN KAWAY XVI
}

\author{
Meidia Refiyanni ${ }^{1}$, H. Zakia $^{2}$ Teuku Cut Adek $^{3}$ \\ Program Studi Teknik Sipil, Fakultas Teknik, Universitas Teuku Umar; \\ e-mail: *refiyannim@utu.co.id
}

\begin{abstract}
ABSTRAC
This study was conducted to analize and identify the factors which will affect the operational cost of two-wheel motor vehicles (motorcycle), analyzing vehicle operating costs of two-wheel motor vehicles (motorcycle) and determining an adequate model for the operational cost of two-wheel motor vehicles (motorcycle) in Tumpuk Ladang Village Kaway XVI Sub District. The dependent variable is the journey that affect operational cost, while the independent variable is the cost of fuel consumption cost of oil (engine oil and transmission oil), the cost of replacemet tires (tire and inner tube), the cost of implementation of the service, the cost of spare parts and unexpected cost. In conducting statistical test, processing data using statistical SPSS software. Then after the statistical test, followed by calculating the operational cost of vehicles of vehicles by type, capacity and the assembly which includes fixed cost and variable cost. Based on the results of this study the cost of fuel consumption and tire replacement is the most influence on operational cost. Model of vehicle operating cost analysis for motorcyle in Tumpok Ladang Village adalah $Y=78,426+$ $0,004 X_{1}+0,001 X_{2}-0,012 X_{3}+0,211 X_{4}-0,929 X_{5}+0,002 X_{6}$.
\end{abstract}

Kata Kunci: Analysis, Vehicle Operational Cost (VOC), Two-Wheels

\section{PENDAHULUAN}

$\mathrm{W}$ arsiti (2003), transportasi yaitu pemindahan barang dan manusia dari tempat asal ke tempat tujuan, atau transportasi adalah perpindahan dari suatu tempat ke tempat lain dengan menggunakan alat pengangkutan, baik yang digerakkan oleh tenaga manusia, hewan (kuda, sapi, kerbau), atau mesin. Konsep transportasi didasarkan pada adanya perjalanan (trip) antara asal (origin) dan tujuan (destination). Di dalam transportasi, terdapat unsur-unsur yang terkait erat dalam berjalannya konsep transportasi itu sendiri. Unsur-unsur tersebut adalah sebagai berikut: manusia yang membutuhkan; barang yang dibutuhkan; kendaraan sebagai alat/sarana; jalan dan terminal sebagai prasarana transportasi; dan organisasi (pengelola transportasi).

Meningkatnya keadaan ekonomi maka kebutuhan hidup meningkat sehingga banyak yang berkeinginan memiliki sarana transportasi sendiri. Dengan memiliki sarana transportasi sendiri masyarakat akan tidak tergantung kepada angkutan umum jika akan melakukan perjalanan ke suatu tempat tertentu. Salah satu faktor pendorong meningkatnya penggunaan sepeda motor adalah biaya operasi kendaraan (BOK) sepeda motor lebih efisien dibandingkan dengan BOK jenis kendaraan lainnya. Dalam konteks tersebut, studi ini bertujuan memodelkan berbagai komponen biaya operasi kendaraan penggunaan sepeda motor di Kota Meulaboh. Studi ini melakukan survei wawancara terhadap pengendara sepeda motor. Survei wawancara bertujuan untuk mendeskripsikan berbagai komponen BOK sepeda motor, baik biaya-biaya langsung maupun biaya tidak langsung.

Analisis data dilakukan dalam rangka membangun model BOK sepeda motor khususnya bagi biaya administrasi, biaya servis berat dan ringan, biaya ban, dan biaya pemakaian oli. Dalam hal ini, berbagai pendekatan model, mulai dari model linier maupun model non-linier dianalisis untuk 
menemukan model-model BOK terbaik sesuai data yang ada. Hasil-hasil pemodelan berbagai komponen BOK tersebut dapat dipergunakan dalam mengestimasi besaran BOK sepeda motor di Kota Meulaboh. Maka untuk itu Penulis melakukan survei penelitian terhadap responden pengguna kendaraan bermotor roda dua yang merupakan penduduk yang berdomisili di Desa Tumpok Ladang Kecamatan Kaway XVI Kabupaten Aceh Barat.

\section{METODE PENELITIAN}

\section{Lokasi Penelitian}

Untuk menghindari penelitian yang terlalu luas dan memberikan arah yang lebih baik maka diperlukan pembatasan-pembatasan. Adapun lokasi yang menjadi wilayah dalam penelitian ini adalah Kota Meulaboh. Penelitian dilakukan dengan cara survei terhadap responden pemilik kendaraan bermotor roda dua yang berada di Desa Tumpok Ladang Kecamatan Kaway XVI dengan mengajukan kuesioner mengenai biaya operasi kendaraan roda dua (sepeda motor).

\section{Metode Pengumpulan Data}

Dalam melakukan penelitian analisis BOK roda dua tau sepeda motor, data yang diperlukan adalah data primer dan data sekunder.

a. Adapun data primer yang diperlukan yaitu:

1. Jenis kendaraan;

2. Tahun perakitan kendaraan;

3. Kapasitas kendaraan;

4. Jumlah perjalanan $(\mathrm{km})$ dalam 1 minggu;

5. Jumlah pemakaian oli mesin (lt) dalam 1 (satu) bulan;

6. Penggantian ban luar dilakukan sekali dalam berapa tahun;

7. Penggantian ban dalam dilakukan sekali dalam berapa tahun;

8. Kecepatan rata-rata yang dilakukan $(\mathrm{km} / \mathrm{jam})$;

9. Pelaksanaan servis dilakukan setelah menempuh berapa km (sekali berapa bulan);

10. Harga beli kendaraan;

11. Besarnya biaya tak terduga rata-rata dalam 1 bulan;

12. Biaya rata-rata penggantian suku cadang dalam 1 tahun.

b. Data sekunder

Data sekunder diperoleh dari instansi seperti samsat, dealer kendaraan, SPBU (Stasiun Pengisian Bahan Bakar Umum), toko onderdil atau suku cadang sepeda motor di daerah Meulaboh. Adapun data sekunder yang diperlukan antara lain:

1. Nilai jual kendaraan dari samsat;

2. Besarnya pajak yang dibayar dari samsat;

3. Harga bahan bakar, oli samping, oli mesin dari SPBU;

4. Biaya servis dari dealer atau bengkel sepeda motor.

\section{Variabel bebas $(\mathbf{X})$}

Variabel bebas (independent) adalah variabel yang dipergunakan untuk memperkirakan. Variabel penelitian ini dikemukakan dalam rangka membantu menjelaskan pokok subjek dan batasan pengertian, variabel tersebut adalah:

$\mathrm{X}_{1}=$ Pemakaian bahan bakar

$\mathrm{X}_{2}=$ Pemakaian oli mesin

$\mathrm{X}_{3}=$ Pemakaian oli transmisi/gear 
$\mathrm{X}_{4}=$ Pergantian ban luar

$\mathrm{X}_{5}=$ Pergantian ban dalam

$\mathrm{X}_{6}=$ Pelaksanaan servis

$\mathrm{X}_{7}=$ Biaya suku cadang

$\mathrm{X}_{8}=$ Biaya tak terduga

\section{Variabel terikat $(\mathbf{Y})$}

Variabel terikat (dependent) adalah variabel yang nilainya akan diperkirakan/diramalkan. Variabel dependen dalam penelitian ini adalah:

$\mathrm{Y}=$ Perjalanan (jumlah perjalanan perminggu)

\section{Metode Analisis Data}

Data-data yang diperoleh dari survei selanjutnya diekstraksi dalam bentuk tabulasi sesuai dengan jenis-jenis biaya operasional kendaraan sepeda motor, seperti tahun produksi, pemakaian bahan bakar minyak (BBM), biaya servis ringan, biaya servis berat, biaya pemakaian ban, lama pemakaian ban biaya pergantian oli, dan lain-lain. Pentabulasian dan pengklasifikasian data sesuai dengan jenis-jenis BOK sepeda motor tersebut. Hasil tabulasi dianalisis sesuai dengan kategori tahun dan usia sepeda motor. Selanjutnya hasil analisis dan ekstraksi tersebut dimodelkan dengan menggunakan berbagai pendekatan regesi lainnya seperti model linier, koefesien kolerasi, koefesien determinan $\left(\mathrm{R}^{2}\right)$, Uji t, Uji F.

\section{Sampel}

Sampel atau contoh adalah sebagian dari populasi yang karakteristiknya hendak diteliti. Dalam penelitian ini sampel yang diambil yaitu penduduk Daerah Tumpok Ladang yang berada di Kecamatan Kaway XVI yang terdiri dari 120 KK (Kepala Keluarga) dengan 495 orang penduduk. Sampel yang baik, yang kesimpulannya dapat dikenakan pada populasi adalah sampel yang bersifat representatif atau yang dapat menggambarkan karakteristik populasi.

Dalam banyak buku yang mencantumkan rumus untuk menentukan ukuran sampel yang dibuat Slovin, khususnya dalam buku-buku metode penelitian. Rumus pembuatan sampel menurut Slovin (2011):

$$
\text { Rumus Slovin (2011) }: \mathrm{n}=\frac{\mathrm{N}}{\mathrm{N} \cdot \mathrm{d}^{2}+1}
$$

Dimana:

$$
\begin{aligned}
& \mathrm{n}=\text { ukuran sampel } \\
& \mathrm{N}=\text { ukuran populasi } \\
& \mathrm{d}=\text { galat pendugaan }
\end{aligned}
$$

\section{Regresi linier berganda}

Menurut Warsiti (2003), setelah semua data terkumpul, data dikompilasi sesuai dengan jenis tahun dan kapasitas (CC). Dari masing-masing kelompok dibuat peramalan model dari variabel independent (bebas) dan variabel dependent (terikat) dengan menggunakan analisis regresi. Adapun bentuk dasar regresi;

$$
\begin{aligned}
& \mathrm{Y}=\mathrm{f}(\mathrm{x}) \\
& \text { Dimana: } \\
& \mathrm{Y}=\text { variabel dependent }(\text { variabel terikat }=\mathrm{BOK} \text { sepeda motor }) \\
& \mathrm{X}=\text { variabel independent }(\text { variabel bebas }=\text { responden) }
\end{aligned}
$$


Pembuatan pemodelan mungkin saja dipengaruhi oleh lebih dari satu variabel independent (variabel bebas), keadaan ini akan terbentuk regresi linier berganda. Analisis regresi linier berganda dimaksudkan untuk mendapatkan persamaan dalam memperkirakan variabel dependent (tak bebas) yang dipengaruhi oleh beberapa variabel dependent (variabel bebas).

\section{Uji t}

Untuk menguji nyata atau tidaknya, statistik uji yang digunakan adalah dengan uji $\mathrm{T}$, formula untuk uji T adalah:

$\mathrm{t}=\frac{\mathrm{r} \sqrt{\mathrm{n}-2}}{\sqrt{1 \mathrm{r}^{2}}}$

Keterangan:

$\begin{array}{ll}\mathrm{t} & =\text { Uji signifikasi korelasi } \\ \mathrm{r} & =\text { Koefisien korelasi yang dihitung } \\ \mathrm{n} & =\text { Jumlah responden yang diuji coba }\end{array}$

\section{Uji F}

Untuk menguji kelayakan koefisien regresi variabel $\mathrm{X}$ terhadap variabel $\mathrm{Y}$ secara keseluruhan, digunakan uji-F dengan rumus:

$\mathrm{F}=\frac{\mathrm{R}^{2}(\mathrm{n}-\mathrm{k}-1)}{\mathrm{k}\left(1-\mathrm{R}^{2}\right)}$

Keterangan:

$\begin{array}{ll}\mathrm{F} & =\text { Nilai F hitung } \\ \mathrm{n} & =\text { Jumlah data } \\ \mathrm{R} & =\text { Koefisien determinan } \\ \mathrm{k}= & \text { Jumlah variabel }\end{array}$

\section{Analisis koefisien kolerasi}

Tujuan dari analisis korelasi adalah untuk melihat hubungan bivariat antara variabel independent dengan variabel dependent, koefisien korelasi untuk setiap variabel berbedabeda dibawah ini:

Tabel 2 Interval Koefisien Kolerasi

\begin{tabular}{cc}
\hline Interval Koefisien & Tingkat Hubungan \\
\hline $0.00-0.199$ & Sangat Rendah \\
$0.20-0.399$ & Rendah \\
$0.40-0.599$ & Sedang \\
$0.60-0.799$ & Kuat \\
$0.80-1.000$ & Sangat Kuat \\
\hline
\end{tabular}

Sumber: Sugiyono, 2007 


\section{HASIL DAN PEMBAHASAN}

\section{Hasil}

Desa Tumpok Ladang Kecamatan Kaway XVI, variabel dependentnya adalah perjalanan, sedangkan pemakaian bahan bakar, pemakaian oli mesin, pemakaian oli transmisi/gear, pergantian ban luar, pergantian ban dalam, pelaksanaan servis, biaya suku cadang dan biaya tak terduga merupakan variabel independent. Hasil perhitungan korelasi antara variabel dependent dan variabel independent dapat dilihat pada tabel4.11 di bawah ini

Tabel 2 Perhitungan Kolerasi dengan Software SPSS

\begin{tabular}{|c|c|c|c|c|c|c|c|c|c|c|}
\hline & & Y & $\mathrm{X}_{1}$ & $\mathrm{X}_{2}$ & $X_{3}$ & $\mathrm{X}_{4}$ & $\mathrm{X}_{5}$ & $\mathrm{X}_{6}$ & $\mathrm{X}_{7}$ & $\mathrm{X}_{8}$ \\
\hline \multirow{9}{*}{$\begin{array}{l}\text { Pearson } \\
\text { Correlati } \\
\text { on }\end{array}$} & Perjalanan & 1.000 & .646 & .360 & .089 & .026 & -.001 & .090 & .100 & -.062 \\
\hline & $\mathrm{BBM}$ & .646 & 1.000 & .391 & .316 & -.141 & -.089 & .100 & .183 & -.061 \\
\hline & Oli mesin & .360 & .391 & 1.000 & .247 & -.149 & -.163 & -.081 & .018 & -.108 \\
\hline & Oli gear & .089 & .316 & .247 & 1.000 & .005 & .063 & .325 & .396 & .055 \\
\hline & Ban luar & .026 & -.141 & -.149 & .005 & $\begin{array}{r}1.00 \\
0\end{array}$ & .986 & .042 & .125 & .102 \\
\hline & Ban dalam & -.001 & -.089 & -.163 & .063 & .986 & 1.000 & .054 & .102 & .093 \\
\hline & Servis & .090 & .100 & -.081 & .325 & .042 & .054 & 1.000 & .147 & .171 \\
\hline & $\begin{array}{l}\text { Suku } \\
\text { cadang }\end{array}$ & -.100 & -.183 & -.018 & -.396 & .125 & .102 & -.147 & $\begin{array}{r}1.00 \\
0\end{array}$ & .135 \\
\hline & Tak terduga & -.062 & -.061 & -.108 & .055 & .102 & .093 & .171 & .135 & 1.000 \\
\hline \multirow{9}{*}{$\begin{array}{l}\text { Sig. (1- } \\
\text { tailed) }\end{array}$} & Perjalanan & . & .000 & .000 & .210 & .406 & .496 & .207 & .180 & .287 \\
\hline & BBM & .000 & & .000 & .002 & .099 & .209 & .182 & .047 & .288 \\
\hline & Oli m & .000 & .000 & & .011 & .08 & .06 & .231 & .437 & .163 \\
\hline & Oli gear & .210 & .002 & .011 & & .483 & .282 & .001 & .000 & .308 \\
\hline & Ban luar & .406 & .099 & .086 & .483 & & .000 & .351 & .127 & .175 \\
\hline & Ban dalam & .496 & .209 & .068 & .282 & .000 & & .311 & .176 & .199 \\
\hline & Servis & .207 & .182 & .231 & .001 & .351 & .311 & & .090 & .059 \\
\hline & $\begin{array}{l}\text { Suku } \\
\text { cadang }\end{array}$ & .180 & .047 & .437 & .000 & .127 & .176 & .090 & & \multirow[t]{2}{*}{.109} \\
\hline & Tak terduga & .287 & .288 & .163 & .308 & .175 & .199 & .059 & .109 & \\
\hline Total & $\mathrm{N}$ & 85 & 85 & 85 & 85 & 85 & 85 & 85 & 85 & 85 \\
\hline
\end{tabular}

Sumber: Pehitungan SPSS, 2015

Dari tabel di atas dapat dilihat hasil perhitungan koefisien korelasi pada kolom Pearson Correlation yang merupakan besarnya nilai persentase hubungan antara variabel $\mathrm{X}$ dengan variabel Y.

\section{Perhitungan Biaya Operasional Kendaraan (BOK)}

Biaya Operasional Kendaraan (BOK) roda dua/sepeda motor dihitung berdasarkan biaya tetap (fixed cost) dan biaya variabel (variable cost). Untuk biaya-biaya variabel dimasukkan ke dalam model persamaan regresi linier berganda, yaitu $\mathrm{Y}=78,426+0,004 \mathrm{X}_{1}+0,001 \mathrm{X}_{2}-0,012 \mathrm{X}_{3}+$ 
$0,211 \mathrm{X}_{4}-0,929 \mathrm{X}_{5}+0,002 \mathrm{X}_{6}+0,000 \mathrm{X}_{7}+0,000 \mathrm{X}_{8}$. Besarnya BOK dihitung untuk setiap 1 (satu) kilometer perjalanan berdasarkan jenis, kapasitas dan tahun perakitannya.

Tabel 3 BOK Total Rata-rata Tiap $1 \mathrm{Km}$

\begin{tabular}{|c|c|c|c|c|c|c|c|}
\hline & \multirow{3}{*}{$\begin{array}{l}\text { Tahun Perakitan/ } \\
\text { Uraian }\end{array}$} & \multicolumn{6}{|c|}{ Kapasitas/Tipe (Rp) } \\
\hline & & $100 \mathrm{CC}$ & $110 \mathrm{CC}$ & $115 \mathrm{CC}$ & $125 \mathrm{CC}$ & $150 \mathrm{CC}$ & $160 \mathrm{CC}$ \\
\hline & & \multirow{2}{*}{ Bebek } & \multicolumn{2}{|c|}{ Skuter Matic } & Bebek & \multicolumn{2}{|c|}{ Sport } \\
\hline \multirow{15}{*}{ 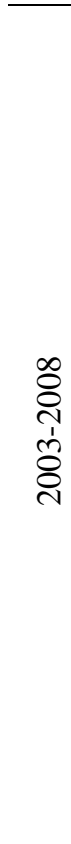 } & \multicolumn{6}{|l|}{ Biaya Tetap (FC): } & \\
\hline & Depresiasi & 79,38 & 97,61 & 64,65 & 104,62 & - & 73,13 \\
\hline & Pajak & 13,22 & 12,84 & 11,98 & 17,06 & - & 14,05 \\
\hline & Jumlah (FC) & 92,60 & 110,44 & 76,63 & 121,68 & - & 87,18 \\
\hline & Biaya Variabel (VC) & \multicolumn{6}{|c|}{$\begin{array}{c}\mathrm{Y}=78,426+0,004 \mathrm{X}_{1}+\begin{array}{c}0,001 \mathrm{X}_{2}-0,012 \mathrm{X}_{3}+0,211 \mathrm{X}_{4}-0,929 \mathrm{X}_{5} \\
+\end{array} \\
0,002 \mathrm{X} 6\end{array}$} \\
\hline & Bahan Bakar (X1) & 119,19 & 159,74 & 198,81 & 153,94 & - & 197,30 \\
\hline & Oli Mesin (X2) & 22,20 & 27,57 & 26,96 & 33,52 & - & 13,45 \\
\hline & Oli Transmisi/Gear(X3) & - & 2,29 & 2,64 & - & - & - \\
\hline & Ban Luar (X4) & 9,54 & 5,50 & 5,54 & 7,03 & - & 5,99 \\
\hline & Ban Dalam (X5) & 2,09 & 1,20 & 1,44 & 1,54 & - & 1,17 \\
\hline & Servis (X6) & 10,37 & 27,45 & 17,64 & 11,94 & - & 10,52 \\
\hline & Suku Cadang (X7) & 61,65 & 42,49 & 32,15 & 54,03 & - & 33,93 \\
\hline & Tak Terduga (X8) & 37,74 & 42,49 & 43,62 & 55,46 & - & 36,65 \\
\hline & Jumlah (VC) & 178,41 & 146,61 & 154,85 & 188,65 & - & 150,02 \\
\hline & TOTAL $(F C+V C)$ & 271,01 & 257,05 & 231,48 & 310,32 & - & 237,21 \\
\hline \multirow{15}{*}{ 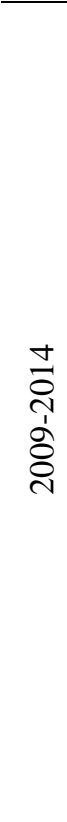 } & Biaya Tetap (FC): & & & & & & \\
\hline & Depresiasi & - & 176,31 & 90,30 & 126,51 & 97,29 & - \\
\hline & Pajak & - & 12,57 & 13,50 & 16,87 & 15,55 & - \\
\hline & Jumlah FC & - & 188,89 & 103,80 & 143,38 & 112,85 & - \\
\hline & Biaya Variabel (VC) & \multicolumn{6}{|c|}{$\begin{array}{c}\mathrm{Y}=78,426+0,004 \mathrm{X}_{1}+0,001 \mathrm{X}_{2}-0,012 \mathrm{X}_{3}+0,211 \mathrm{X}_{4}-0,929 \mathrm{X}_{5} \\
+0,002 \mathrm{X} 6\end{array}$} \\
\hline & Bahan Bakar (X1) & - & 154,03 & 244,66 & 153,36 & 130,12 & - \\
\hline & Oli Mesin (X2) & - & 28,64 & 35,09 & 21,27 & 17,28 & - \\
\hline & Oli Transmisi/Gear (X3) & - & 2,47 & 2,97 & - & - & - \\
\hline & Ban Luar (X4) & - & 6,13 & 5,33 & 5,65 & 5,22 & - \\
\hline & Ban Dalam (X5) & - & 1,34 & 1,38 & 1,24 & 1,01 & - \\
\hline & Servis (X6) & - & 15,92 & 18,17 & 14,55 & 9,88 & - \\
\hline & Suku Cadang (X7) & - & 22,09 & 21,01 & 32,25 & 25,41 & - \\
\hline & Tak Terduga (X8) & - & 42,72 & 29,02 & 42,33 & 19,65 & - \\
\hline & Jumlah VC & - & 143,93 & 167,16 & 153,72 & 124,21 & - \\
\hline & TOTAL $(F C+V C)$ & - & 332,82 & 270,96 & 297,09 & 237,06 & - \\
\hline
\end{tabular}

Sumber: Perhitungan, 2015 
Untuk mengetahui BOK total maksimum menurut jenis, kapasitas dan tahun perakitannya dapat dilihat pada tabel 4.32 di bawah ini.

Tabel 4 BOK Total Maksimum Tiap $1 \mathrm{Km}$

\begin{tabular}{|c|c|c|c|c|c|c|c|}
\hline & \multirow{3}{*}{$\begin{array}{l}\text { Tahun Perakitan/ } \\
\text { Uraian }\end{array}$} & \multicolumn{6}{|c|}{ Kapasitas/Tipe (Rp) } \\
\hline & & $100 \mathrm{CC}$ & $110 \mathrm{CC}$ & $115 \mathrm{CC}$ & $125 \mathrm{CC}$ & $150 \mathrm{CC}$ & $160 \mathrm{CC}$ \\
\hline & & Bebek & \multicolumn{2}{|c|}{ Skuter Matic } & Bebek & \multicolumn{2}{|c|}{ Sport } \\
\hline \multirow{15}{*}{ 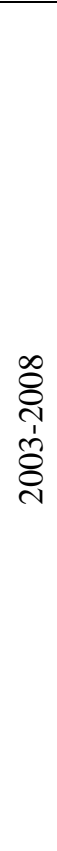 } & \multicolumn{7}{|l|}{ Biaya Tetap (FC): } \\
\hline & Depresiasi & 98,00 & 104,11 & 93,11 & 164,49 & - & 88,60 \\
\hline & Pajak & 17,64 & 13,69 & 15,21 & 26,71 & - & 16,03 \\
\hline & Jumlah (FC) & 115,64 & 117,81 & 108,32 & 191,20 & - & 104,63 \\
\hline & Biaya Variabel (VC) & \multicolumn{6}{|c|}{$\begin{array}{c}\mathrm{Y}=78,426+0,004 \mathrm{X}_{1}+0,001 \mathrm{X}_{2}-0,012 \mathrm{X}_{3}+0,211 \mathrm{X}_{4}-0,929 \mathrm{X}_{5} \\
+0,002 \mathrm{X} 6\end{array}$} \\
\hline & Bahan Bakar (X1) & 143,03 & 159,74 & 260,71 & 159,74 & - & 197,30 \\
\hline & Oli Mesin (X2) & 28,61 & 39,93 & 46,98 & 43,82 & - & 24,66 \\
\hline & Oli Transmisi/Gear (X3) & - & 2,44 & 3,62 & - & - & - \\
\hline & Ban Luar (X4) & 12,71 & 6,66 & 8,15 & 12,78 & - & 8,22 \\
\hline & Ban Dalam (X5) & 2,78 & 1,46 & 2,11 & 2,80 & - & 1,60 \\
\hline & Servis (X6) & 16,69 & 34,94 & 50,69 & 22,37 & - & 11,51 \\
\hline & Suku Cadang (X7) & 135,08 & 47,54 & 54,32 & 103,84 & - & 50,24 \\
\hline & Tak Terduga (X8) & 71,51 & 47,54 & 108,63 & 189,69 & - & 54,80 \\
\hline & Jumlah (VC) & 285,75 & 166,67 & 242,28 & 372,78 & & 184,56 \\
\hline & TOTAL $(\mathrm{FC}+\mathrm{VC})$ & 401,39 & 284,48 & 350,60 & 563,98 & - & 289,19 \\
\hline \multirow{15}{*}{ 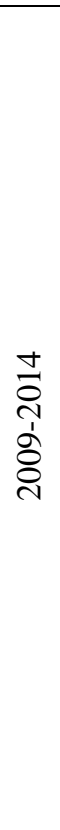 } & \multicolumn{7}{|l|}{ Biaya Tetap (FC): } \\
\hline & Depresiasi & - & 456,51 & 115,87 & 341,23 & 103,02 & - \\
\hline & Pajak & - & 16,40 & 16,84 & 27,80 & 16,47 & - \\
\hline & Jumlah FC & - & 472,91 & 132,71 & 369,03 & 119,48 & - \\
\hline & Biaya Variabel (VC) & \multicolumn{6}{|c|}{$\begin{array}{c}\mathrm{Y}=78,426+0,004 \mathrm{X}_{1}+0,001 \mathrm{X}_{2}-0,012 \mathrm{X}_{3}+0,211 \mathrm{X}_{4}-0,929 \mathrm{X}_{5} \\
+0,002 \mathrm{X} 6\end{array}$} \\
\hline & Bahan Bakar (X1) & - & 161,15 & 260,71 & 153,36 & 130,12 & - \\
\hline & Oli Mesin (X2) & - & 41,71 & 47,40 & 38,34 & 18,30 & - \\
\hline & Oli Transmisi/Gear (X3) & - & 3,04 & 4,35 & - & - & - \\
\hline & Ban Luar (X4) & - & 13,90 & 8,15 & 8,52 & 6,10 & - \\
\hline & Ban Dalam (X5) & - & 3,04 & 2,11 & 1,86 & 1,19 & - \\
\hline & Servis (X6) & - & 40,29 & 25,35 & 33,55 & 12,65 & - \\
\hline & Suku Cadang (X7) & - & 76,74 & 44,44 & 50,21 & 27,11 & - \\
\hline & Tak Terduga (X8) & - & 138,13 & 43,45 & 82,16 & 28,46 & - \\
\hline & Jumlah VC & - & 294,13 & 167,16 & 211,58 & 134,75 & - \\
\hline & TOTAL (FC + VC) & - & 767,04 & 299,87 & 580,60 & 254,23 & - \\
\hline
\end{tabular}

Sumber: Perhitungan, 2015 


\section{Pembahasan}

Dari data yang diperoleh ditentukan variabel terikat (dependent) dan variabel bebas (independent). Dalam hal ini, perjalanan merupakan variabel terikat (dependent) sedangkan pemakaian bahan bakar, pemakaian oli, pergantian ban, servis, biaya suku cadang, dan biaya tak terduga termasuk variabel bebas (independent). Pada pembahasan ini dijelaskan tentang faktor yang mendominasi yang mempengaruhi perjalanan yaitu biaya operasional kendaraan (BOK), model analisis perjalanan, dan biaya total operasioal kendaraan tersebut berdasarkan jenis, kapasitas dan tahun perakitannya.

\section{Faktor dominasi yang mempengaruhi biaya operasional kendaraan bermotor roda dua (sepeda motor)}

Uji t dari analisis regresi linier berganda yang perhitungannya menggunakan software SPSS 20dilakukan untuk mengetahui faktor-faktor apa saja (variabel bebas $X_{n}$ ) yang mempunyai pengaruh secara parsial dan signifikan terhadap perjalanan (variabel terikat $\mathrm{Y}$ ) dalam hal ini biaya operasional kendaraannya (BOK). Dari hasil perhitungan uji t tersebut diperoleh bahwa:

1. Nilai $t_{\text {hitung }}$ variabel biaya pemakaian bahan bakar $\left(X_{1}\right)$ sebesar 8,644 lebih besar dari nilai $t_{\text {tabel }}$ yaitu sebesar 1,292, sedangkan probabilitasnya $\mathrm{Sig}_{\text {hitung }}$ sebesar 0,000 lebih kecil dari 0,05 (derajat signifikan tingkat kesalahan yang ditentukan). Maka variabel bebas $\mathrm{X}_{1}$ berpengaruh secara parsial dan signifikan terhadap variabel bebas $\mathrm{Y}$.

2. Nilai $t_{\text {hitung }}$ variabel biaya pergantian ban luar $\left(X_{4}\right)$ sebesar 4,647 lebih besar dari nilai $t_{\text {tabel }}$ yaitu sebesar 1,292, sedangkan probabilitasnya $\mathrm{Sig}_{\text {hitung }}$ sebesar 0,000 lebih kecil dari 0,05 (derajat signifikan tingkat kesalahan yang ditentukan). Maka variabel bebas $\mathrm{X}_{4}$ berpengaruh secara parsial dan signifikan terhadap variabel bebas Y.

Maka dapat diketahui biaya pemakaian bahan bakar dan biaya pergantian ban luar mempunyai pengaruh yang mendominasi terhadap biaya operasional kendaraan. Dari perhitungan koefisien korelasi diperoleh angka koefisien variabel $\mathrm{X}_{1}$ sebesar 0,646 dan angka koefisien variabel $\mathrm{X}_{4}$ sebesar 0,026 . Maka model yang didapat adalah sebagai berikut:

$$
\mathrm{Y}=78,426+0,646 \mathrm{X}_{1}+0,026 \mathrm{X}_{4}
$$

Dari model persamaan tersebut di atas memberi penjelasan jika biaya pemakaian bahan bakar bertambah satu satuan, dan juga biaya pemakaian oli mesin bertambah satu satuan, maka perjalanan dalam hal ini merupakan biaya operasionalnya akan mengalami peningkatan sebagai berikut:

$$
\begin{aligned}
\mathrm{Y} & =78,426+0,646 \mathrm{X}_{1}+0,026 \mathrm{X}_{4} \\
\mathrm{Y} & =78,426+0,646(1)+0,026(1) \\
& =\mathrm{Rp} 79,098 \mathrm{Km}
\end{aligned}
$$

\section{Model analisis biaya operasional kendaraan bermotor roda dua (sepeda motor)}

Berdasarkan hasil dari perhitungan menggunakan bantuan software SPSS diperoleh model persamaan regresi linier berganda analisis biaya operasional kendaraan roda dua (sepeda motor) di Desa Tumpok Ladang Kecamatan Kaway XVI, yaitu sebagai berikut:

$$
\begin{aligned}
\mathrm{Y}= & 78,426+0,004 \mathrm{X}_{1}+0,001 \mathrm{X}_{2}-0,012 \mathrm{X}_{3}+0,211 \mathrm{X}_{4}-0,929 \mathrm{X}_{5}+ \\
& 0,002 \mathrm{X}_{6}+0,000 \mathrm{X}_{7}+0,000 \mathrm{X}_{8}
\end{aligned}
$$

Dikarenakan koefisien pada variabel bebas $\mathrm{X}_{7}$ dan $\mathrm{X}_{8}$ adalah 0 (nol), maka model persamaan regresinya analisis biaya operasional kendaraan roda dua (sepeda motor) menjadi:

$\mathrm{Y}=78,426+0,004 \mathrm{X}_{1}+0,001 \mathrm{X}_{2}-0,012 \mathrm{X}_{3}+0,211 \mathrm{X}_{4}-0,929 \mathrm{X}_{5}+0,002 \mathrm{X}_{6}$

Dari model persamaan tersebut di atas dapat dijelaskan bahwa seandainya biaya pemakaian bahan bakar $\left(\mathrm{X}_{1}\right)$, biaya pemakaian oli mesin $\left(\mathrm{X}_{2}\right)$, biaya pemakaian oli transmisi/gear $\left(\mathrm{X}_{3}\right)$, biaya pergantian ban luar $\left(\mathrm{X}_{4}\right)$, biayapergantian ban dalam $\left(\mathrm{X}_{5}\right)$, dan biaya pelaksanaan servis $\left(\mathrm{X}_{6}\right)$ 
masing-masing bertambah satu satuan maka perjalanan dalam hal ini merupakan biaya operasionalnya akan mengalami perubahan sebagai berikut:

$$
\begin{aligned}
\mathrm{Y} & =78,426+0,004 \mathrm{X}_{1}+0,001 \mathrm{X}_{2}-0,012 \mathrm{X}_{3}+0,211 \mathrm{X}_{4}-0,929 \mathrm{X}_{5}+0,002 \mathrm{X}_{6} \\
\mathrm{Y} & =78,426+0,004(1)+0,001(1)-0,012(1)+0,211(1)-0,929(1)+0,002(1) \\
& =\mathrm{Rp} 77,715 / \mathrm{km}
\end{aligned}
$$

\section{Analisis biaya operasional kendaraan bermotor roda dua (sepeda motor)}

Dari hasil perhitungan Biaya Operasional Kendaraan (BOK) roda dua (sepeda motor) yang telah dilakukan, maka diperoleh jumlah total rata-rata dan jumlah total maksimum biaya operasionalnya tiap $1 \mathrm{~km}$ perjalanan. Rekapitulasi Biaya Operasional Kendaraan (BOK) total ratarata yang dikelompokkan berdasarkan jenis, kapasitas dan tahun perakitan kendaraan

Tabel 5 Rekapitulasi BOK Total Rata-rata Tiap $1 \mathrm{Km}$

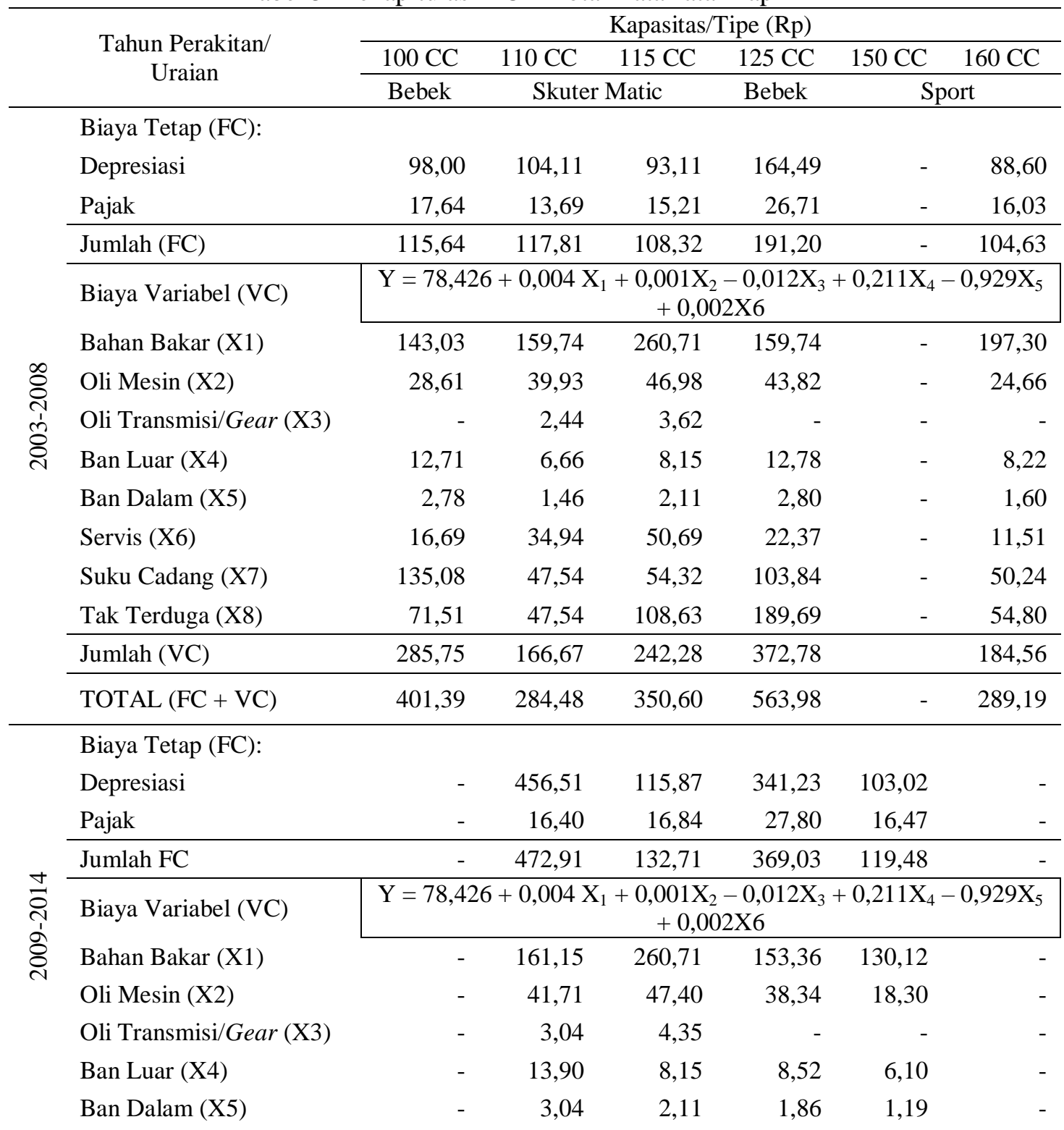




\begin{tabular}{lrrrrrr} 
Servis (X6) & - & 40,29 & 25,35 & 33,55 & 12,65 & - \\
Suku Cadang (X7) & - & 76,74 & 44,44 & 50,21 & 27,11 & - \\
Tak Terduga (X8) & - & 138,13 & 43,45 & 82,16 & 28,46 & - \\
\hline Jumlah VC & - & 294,13 & 167,16 & 211,58 & 134,75 & - \\
\hline TOTAL (FC + VC) & - & 767,04 & 299,87 & 580,60 & 254,23 & - \\
\hline
\end{tabular}

Sumber: Perhitungan, 2015

Dari tabel dan diagram di atas, dapat kita simpulkan bahwa besarnya biaya operasional kendaraan bermotor roda dua rata-rata tiap satu kilometer perjalanan di Desa Tumpok Ladang Kecamatan Kaway XVI adalah sebagai berikut:

1. BOK rata-rata kapasitas kendaraan 100 CC (jenis bebek) tahun perakitan 2003-2008 yaitu sebesar Rp271,01;

2. BOK rata-rata kapasitas kendaraan $110 \mathrm{CC}$ (jenis skuter matic) tahun perakitan 2003-2008dan 2009-2014 yaitu sebesar Rp257,05 dan Rp332,82;

3. BOK rata-rata kapasitas kendaraan 115 CC (jenis skuter matic) tahun perakitan 2003-2008dan 2009-2014 yaitu sebesar Rp231,48 dan Rp270,96;

4. BOK rata-rata kapasitas kendaraan 125 CC (jenis bebek) tahun perakitan 2003-2008dan 20092014 yaitu sebesar Rp310,32 dan Rp297,09;

5. BOK rata-rata kapasitas kendaraan $160 \mathrm{CC}$ (jenis sport) tahun perakitan 2003-2008 yaitu sebesar Rp237,21;

6. BOK rata-rata kapasitas kendaraan $150 \mathrm{CC}$ (jenis sport) tahun perakitan 2009-2014 yaitu sebesar Rp237,06.

Sedangkan rekapitulasi Biaya Operasional Kendaraan (BOK) total maksimum yang dikelompokkan berdasarkan jenis, kapasitas dan tahun perakitan kendaraan.

Tabel 6 Rekapitulasi BOK Total Maksimum Tiap $1 \mathrm{Km}$

\begin{tabular}{|c|c|c|c|c|c|c|}
\hline \multirow{3}{*}{$\begin{array}{l}\text { Tahun Perakitan/ } \\
\text { Uraian }\end{array}$} & \multicolumn{6}{|c|}{ Kapasitas/Tipe (Rp) } \\
\hline & $100 \mathrm{CC}$ & $110 \mathrm{CC}$ & $115 \mathrm{CC}$ & $125 \mathrm{CC}$ & $150 \mathrm{CC}$ & $160 \mathrm{CC}$ \\
\hline & Bebek & \multicolumn{2}{|c|}{ Skuter Matic } & Bebek & \multicolumn{2}{|c|}{ Sport } \\
\hline \multicolumn{7}{|c|}{ Tahun Perakitan 2003-2008: } \\
\hline Biaya Tetap (FC) & 92,60 & 110,44 & 76,63 & 121,68 & - & 87,18 \\
\hline Biaya Variabel (VC) & 178,41 & 146,61 & 154,85 & 188,65 & - & 150,02 \\
\hline Total $(\mathrm{FC}+\mathrm{VC})$ & 271,01 & 257,05 & 231,48 & 310,32 & - & 237,21 \\
\hline \multicolumn{7}{|c|}{ Tahun Perakitan 2009-2014: } \\
\hline Biaya Tetap (FC) & - & 188,89 & 103,80 & 143,38 & 112,85 & - \\
\hline Biaya Variabel (VC) & - & 143,93 & 167,16 & 153,72 & 124,21 & - \\
\hline Total $(\mathrm{FC}+\mathrm{VC})$ & - & 332,82 & 270,96 & 297,09 & 237,06 & - \\
\hline
\end{tabular}

Sumber: Perhitungan, 2015

Dari tabel dan diagram di atas, dapat kita simpulkan bahwa besarnya biaya operasional kendaraan bermotor roda dua maksimum tiap satu kilometer perjalanan di Desa Tumpok Ladang Kecamatan Kaway XVI adalah sebagai berikut: 
1. BOK maksimum kapasitas kendaraan $100 \mathrm{CC}$ (jenis bebek) tahun perakitan 2003-2008 yaitu sebesar Rp401,39;

2. BOK maksimum kapasitas kendaraan 110 CC (jenis skuter matic) tahun perakitan 2003-2008 dan 2009-2014 yaitu sebesar Rp284,48 dan Rp767,04;

3. BOK maksimum kapasitas kendaraan 115 CC (jenis skuter matic) tahun perakitan 2003-2008 dan 2009-2014 yaitu sebesar Rp350,60 dan Rp580,60;

4. BOK maksimum kapasitas kendaraan 125 CC (jenis bebek) tahun perakitan 2003-2008 dan 2009-2014 yaitu sebesar Rp563,98 dan Rp580,60;

5. BOK maksimum kapasitas kendaraan 160 CC (jenis sport) tahun perakitan 2003-2008 yaitu sebesar Rp289,19;

6. BOK Kapasitas kendaraan 150 CC (jenis sport) tahun perakitan 2009-2014 yaitu sebesar Rp254,23.

\section{KESIMPULAN DAN SARAN}

\section{Kesimpulan}

Setelah dilakukan perhitungan-perhitungan untuk mendapatkan hasil dan uraian pembahasan mengenai analisis Biaya Operasional Kendaraan (BOK) bermotor roda dua (sepeda motor) di Desa Tumpok Ladang Kecamatan Kaway XVI, dapat diambil beberapa kesimpulan yaitu sebagai berikut:

1 Faktor-faktor dominasi yang mempengaruhi biaya operasional di Desa Tumpok Ladang adalah biaya pemakaian bahan bakar dan biaya pergantian ban luar.

2 Analisis biaya operasional kendaraan dilakukan dengan cara serangkaian pengujian statistik seperti analisis koefisien korelasi, regresi linier berganda, analisa koefisien determinasi $\left(\mathrm{R}^{2}\right)$, uji $\mathrm{t}$ dan uji $\mathrm{F}$ terhadap variabel terikat (dependent) dan variabel bebas (independent). Variabel terikat adalah perjalanan dalam hal ini yang mempengaruhi biaya operasionalnya, sedangkan variabel bebas adalah biaya pemakaian bahan bakar, biaya pelumas (oli mesin dan oli transmisi/gear), biaya pergantian ban (ban luar dan ban dalam), biaya pelaksanaan servis, biaya suku cadang, dan biaya tak terduga. Perhitungan biaya operasional meliputi biaya tetap dan biaya variabel.

3 Model analisis biaya operasional kendaraan di Desa Tumpok Ladang adalah:

$\mathrm{Y}=78,426+0,004 \mathrm{X}_{1}+0,001 \mathrm{X}_{2}-0,012 \mathrm{X}_{3}+0,211 \mathrm{X}_{4}-0,929 \mathrm{X}_{5}+0,002 \mathrm{X}_{6}$

Adapun Biaya Operasional Kendaraan (BOK) total maksimum tiap $1 \mathrm{~km}$ perjalanan di Desa Tumpok Ladang Kecamatan Kaway XVI yang dikelompokkan berdasarkan jenis, kapasitas dan tahun perakitan kendaraan yaitu sebagai berikut:

- BOK kapasitas kendaraan 100 CC (jenis bebek) tahun perakitan 2003-2008 yaitu sebesar Rp401,39;

- BOK kapasitas kendaraan 110 CC (jenis skuter matic) tahun perakitan 2003-2008 dan 2009-2014 yaitu sebesar Rp284,48 dan Rp767,04;

- BOK maksimum kapasitas kendaraan 115 CC (jenis skuter matic) tahun perakitan 20032008 dan 2009-2014 yaitu sebesar Rp350,60 dan Rp580,60;

- BOK maksimum kapasitas kendaraan 125 CC (jenis bebek) tahun perakitan 2003-2008 dan 2009-2014 yaitu sebesar Rp563,98 dan Rp580,60;

- BOK maksimum kapasitas kendaraan 160 CC (jenis sport) tahun perakitan 2003-2008 yaitu sebesar Rp289,19;

- BOK Kapasitas kendaraan 150 CC (jenis sport) tahun perakitan 2009-2014 yaitu sebesar Rp254,23. 


\section{Saran}

1. Sebagai bahan perbandingan mengenai analisa Biaya Operasional Kendaraan (BOK) roda dua (sepeda motor) sebaiknya dilakukan penelitian serupa untuk daerah lain.

2. Disarankan kepada pengguna sepeda motor untuk memperhatikan faktor merk ataupun jenis sepeda motor dan biaya operasionalnya pada saat ingin membeli kendaraan tersebut, sehingga dapat mempertimbangkan biaya langsung dan tak langsung pada saat memiliki sepeda motor.

3. Diharapkan kepada pengguna sepeda motor untuk dapat memperhatikan ketentuan-ketentuan dalam mengoperasikan kendaraannya sesuai dengan aturan pabrikan sepeda motor tersebut, ataupun sesuai dengan kebijakan daerah setempat. Sehingga tidak terjadi hal-hal yang tidak diinginkan ataupun kerugian yang dapat mempengaruhi biaya operasional kendaraan tersebut.

\section{DAFTAR PUSTAKA}

[1] Anonim 2014, Tugas Akhir Heri Safrizal, Analisa Model Bangkitan Perjalanan Pada Daerah Relokasi (Studi Kasus Relokasi Desa Pasi Mesjid), Universitas Teuku Umar

[2] Anonim 2013, Tugas Akhir Muzahar, Analisa Model Bangkitan Perjalanan Pada Daerah Relokasi (Studi Kasus Desa Blang Beurandang), Universitas Teuku Umar

[3] Amirin, Tantang M. 2011, Populasi dan Ukuran Sampel Rumus Slovin, A blog Of Yogyakarta State-Universitas Blogs, Yogyakarta.

[4] Sugiyono, 2001. Metoda Penelitian Administrasi dilengkapi dengan Metode R\&D. Alfabeta, Bandung.

[5] Tamin, O.Z. 1997, Perencanaan dan Pemodelan Transportasi, Edisi Pertama,Penerbit ITB, Bandung.

[6] Warsiti, 2003. Analisis Biaya Operasi Kendaraan Bermotor Roda Dua di Semarang, Universitas Diponegoro, Semarang.

[7] Sarwono, J. 2013, 12 Jurus Ampuh SPSS untuk Riset Skripsi, Elexmedia Komputindo Kompas Gramedia, Jakarta 